\title{
ESTIMATION AND CONTROL ALGORITHMS OF MANUFACTURING AND SALES PROCESSES UNDER CONDITIONS OF INCOMPLETE INFORMATION
}

\author{
V.I. Shiryaev, shiriaevvi@susu.ru, \\ A.A. Bragina, braginaaa@susu.ru \\ South Ural State University, Chelyabinsk, Russian Federation
}

\begin{abstract}
Approaches to the enterprise control under conditions of certainty and uncertainty are considered. Economic and mathematical model of manufacturing and sales enterprise is constructed in the form of nonlinear difference equations, determining the correlation of material, information and financial flows within the enterprise. This allows solving the problems of analysis and control of economic processes both in the enterprise in general and in its subdivisions. The solution to one of the possible problems of enterprise adaptation to changeable market conditions is considered, and the method of estimate of adaptation efficiency is introduced. The problems of enterprise parameter optimization and optimal control of the enterprise behavior under conditions of incomplete information and market environment changes are stated and solved. The algorithm of estimation of state vector of the system is obtained for the conditions of incomplete information. The results of modeling are given. The economic and mathematical model and the algorithms of estimation and control can be applied in the design of the enterprise automated control systems software.

Keywords: parametric optimization, optimal control, control under conditions of incomplete information, filtration, guaranteed estimation.
\end{abstract}

\section{Introduction}

Optimization of an enterprise control is the choice of many alternatives. If the application of mathematical optimization techniques is possible, at the initial stage of research a mathematical model of business processes should be constructed, and the criterion of success of the enterprise should be formulated. Finding optimal solutions is carried out within the constraints defined by the business process models, and this process is complicated by the uncertainties caused by changes in the market environment, which affects the decision-making process.

In the process of modeling of microeconomic processes the correlation of information, material and financial flows of the enterprise should always be taken into account. The approach proposed by John Forrester [1] is taken as a basis in this paper. It involves building a dynamic model of manufacturing and sales enterprise, which would reveal the interaction of the elements of its structure, material, financial and information flows. Such models can be used in sales and inventory management of the enterprise, depending on the anticipated needs, when creating GALS-technologies that unite all divisions of the enterprise involved in the design, planning and production, as well as services of supply, sales of finished products, conversion and utilization. Various approaches to the dynamic modeling of enterprises are given in [2-12].

To reduce the level of uncertainty in the process of management the problem of estimating the state vectors and enterprise parameters according to available a priori and a posteriori information should be solved. The solution of the estimation problem with the known statistical characteristics of unknown factors, using filtration methods and in case of their absence - using a guaranteed estimation algorithms, are discussed in [13-23]. The paper continues the research of [15, 16, 19-23].

\section{Economic and mathematical model of enterprise}

We shall examine the enterprise dealing with the production and sales of one type of product [1] that is considered to be a uniform system, where the flow of customers' applications for products arrives in a sales unit. The sales unit distributes them at manufacturing site. From the manufacturing unit the flow of finished products arrives back in the sales unit. Part orders are delivered due to productive supplies, another part is delivered specially on request of the sales unit. The manufacturing unit includes 


\section{Управление в социально-экономических системах}

production both to satisfy incoming orders and to replenish the productive stock. These goods are transferred with some time delays to the distributing storage of the sales unit, from where they are delivered to the customers. When modeling, it is assumed that production requires labor costs and its rate depends on the number of workers.

\subsection{Construction of a simplified model of the enterprise}

Economic and mathematical model of enterprise is presented by the system of a nonlinear difference equation of the form [20-23].

$$
x_{k+1}=A(p) x_{k}+F\left(x_{k}, w_{k}, p\right)+B(p) u_{k}+D(p) w_{k},
$$

where $k$ is discrete time with a sampling period $T, x_{k} \in R^{n}, u_{k} \in R^{m}, w_{k} \in R^{r}$ are state, command and disturbance vectors, respectively, describing the system behavior temporally, $p \in R^{t}$ is a vector of parameters of the enterprise, $A(p), B(p), D(p)$ are matrices, entries of which are fixed numbers, $F(\cdot, \cdot, \cdot)$ is nonlinear vectors-function.

The coordinates of disturbance vector $w_{k}$ determine the constituents that have a direct impact on the enterprise performance and depend only on the market situation: product demand, material costs, time of payment of the salable product cost, time of delivery of the materials in the manufacturing units of the enterprise, disturbance in the flow of the workforce.

Equations that determine the coordinates of the vectors of state $x_{k}$, command $u_{k}$ and parameters $p$ are solved for each value $k$ with time interval $T$ and specified initial data [20-22]. We shall consider some equations of the system (1). For example, the equation of supply due to manufacturing inventory $x_{1, k}$ on request of the sales unit, which has already been placed, but has not implemented yet, is of the form

$$
x_{1, k+1}=x_{1, k}+T\left(u_{0, k}-f_{1, k}\right),
$$

where $u_{0, k}$ is a rate of requirements (demand), met due to manufacturing inventory (units per week), $f_{1, k}$ is product shipping time from the manufacturing inventory (units per week). On the hypothesis that the rate of order fulfillment determines the volume of unfilled orders and the lag of their fulfillment, depending on available inventory, we will get the equation for the determination of delivery rate $f_{1, k}=\frac{x_{1, k}}{w_{1, k}}$, where $w_{1, k}$ is order fulfillment lag (weeks).

The actual stock of finished products $x_{2, k}$ at the place of production (units) is determined by the equation:

$$
x_{2, k+1}=x_{2, k}+T\left(u_{1, k}-\frac{x_{2, k}}{p_{0}}\right),
$$

where $u_{1, k}$ is a rate of release of products (units per week) to compensate the manufacturing inventory, $p_{0}$ is product shipping time. The stock of materials $x_{3, k}$, determined by the volume of their income to the place of production $x_{4, k}$ and by the rate of expenditure in the process of manufacture $p_{1} x_{5, k}$ is given by the equation

$$
x_{3, k+1}=x_{3, k}+T\left(x_{4, k}-p_{1} x_{5, k}\right),
$$

where $x_{5, k}$ is a number of production workers (people), $p_{1}$ is workforce productivity at the place of production (units per people-week). The number of production workers $x_{5, k}$ is determined by the equation

$$
x_{5, k+1}=x_{5, k+1}+T\left(x_{6, k+1}-u_{2, k}-w_{2, k}\right),
$$

where $x_{6, k}$ is a number of workers, beginning the work, $u_{2, k}$ is a rate of redundancy of workers (people per week) in connection with expiration of a contract, $w_{2, k}$ is a rate of voluntary redundancy of workers (people per week). 
The equation of desirable production output $x_{7, k}$ (units per week) is of the form

$$
x_{7, k+1}=w_{3, k}+\frac{1}{\tau_{1}}\left(x_{8, k}-x_{2, k}+x_{9, k}-x_{10, k}+x_{11, k}-x_{12, k}\right),
$$

where $w_{3, k}$ is requirements, received with production (units per week), $x_{8, k}$ is a desirable inventory in the manufacturing unit (units), $x_{9, k}$ is a desirable level of orders transmitted through the channels (units), determined by manufacturing requirements, $x_{10, k}$ is an actual level of orders in channels issued by the manufacturing unit (units), $x_{11, k}$ is an actual level of unfilled orders in the manufacturing unit (units), $x_{12, k}$ is an average number of unfilled orders for the manufacturing unit (units), $\tau_{1}$ is lag of inventory control in the manufacturing unit (weeks).

In the equation (6) the pace of sales, the state of inventory unfinished and unfilled goods have been taken into account. The volume of production of commodities $x_{13, k}$ is chosen as the smallest one out of desirable and constrained with productive capacity: $x_{13, k}=\min \left\{x_{7, k}, \beta\right\}$, where $\beta$ is a constant, characterizing maximum productive capacity.

\subsection{Construction of expanded model of the enterprise}

Expanded model of the enterprise describes its activities in a more detailed way. It is based on observations of a real enterprise, where the interaction between sales and manufacturing units is determined by the flow of the production orders received from customers, by the flow of finished goods in the opposite direction, and information on the delay of order execution by the enterprise. The expanded model built is described by a system of nonlinear differential equations of the form

$$
x_{k+1}=\Phi\left(x_{k}, w_{k}, u_{k}, p\right),
$$

where $k$ is discrete time with a sampling period $T, x_{k} \in R^{n}, u_{k} \in R^{m}, w_{k} \in R^{r}$ are vectors of state, command and disturbances, respectively, describing the system, behavior in time, $p \in R^{s}$ is a vector of parameters of the enterprise, $\Phi(\cdot, \cdot, \cdot)$ is a nonlinear vector-function, allowing piecewise-linear approximation.

The components of the expanded models are mathematical models of sales and manufacturing units that are described by equations similar to the simplified model $(2-6)[20,21]$. Thus, we shall consider the impact of the factors such as labor force, flow of funds, profit and other on the enterprise activities.

Production requires high labor costs, and providing enterprise with personnel and the regulation of its number are important issues. Production output in accordance with the average level of orders is provided with the number of workers $x_{14, k}$ (people), defined by the equation $x_{14, k}=\frac{x_{15, k}}{C_{1}}$, where $x_{15, k}$ is the average level of incoming orders (units per week), $C_{1}$ is a labor productivity in the enterprise (unit per people-weeks).

\subsubsection{Personnel equations}

The requirements for the number of personnel to implement the volume of portfolio of orders depend on its estimation. In many cases, it is advisable to take a value as an estimation that would indicate how long these orders can promote the production of: $x_{16, k}=\tau_{2} x_{15, k}$, where $\tau_{2}$ is delay in a normal portfolio of orders at the place of production (weeks). Since the actual portfolio of orders is different from the normal one, the amount of labor force is set to adjust the volume of portfolio of orders to the desired level: $x_{17, k}=\frac{x_{18, k}-x_{19, k}}{C_{1} p_{2}}$. Here $x_{17, k}$ is a number of workers to control unfilled orders (people), $x_{18, k}$ is total volume of the portfolio of unfilled orders at the place of manufacture (units), $x_{19, k}$ is normal volume of the portfolio of orders (units), $p_{2}$ is time of unfilled orders by the manufacturing unit (weeks). 


\section{Управление в социально-экономических системах}

Desirable level of labor force $x_{20, k}$, involved in production (people) can be found from the equation: $x_{20, k}=x_{14, k}+x_{21, k}-x_{22, k}$, where $x_{21, k}$ is a number of workers who control the unfilled orders (people), $x_{22, k}$ is a number of workers who produce excessive inventory (people).

The difference between desirable and actual levels of labor force defines its surplus and deficit: $x_{23, k}=x_{20, k}-x_{24, k}$. Here $x_{23, k}$ is irrelevance between desirable and actual number of workers at the place of manufacture (people), $x_{24, k}$ is an actual number of workforce (people). Since $x_{23, k}>0$ we need to hire a certain number of workers, and when $x_{23, k}<0$ we need to reduce this number.

When making decision on the employment of workers, the critical deviation of the number of workers and the rate of existing irrelevance elimination should be taken into account. Their correlation is determined by the equation $x_{25, k}=\frac{1}{p_{3}}\left(x_{23, k}-C_{2} x_{26, k}\right)$, where $x_{25, k}$ is a changed rate of employment (people per week), $p_{3}$ is time of change of the number of workers (weeks), $C_{2}$ is a critical value of irrelevance of the levels of labor force at the place of manufacture as a part of the total number of production workers (people per week), $x_{26, k}$ is production personnel determined be the total number of workers at the present time and those who undergoes training at the place of manufacture before beginning of work.

Labor shedding rate is determined in the same way:

$x_{27, k}=\frac{1}{p_{3}}\left(x_{23, k}+C_{2} x_{26, k}\right)$, where $x_{27, k}$ is a changed redundancy rate (people per week).

The decision on hiring of labor force is made only when the value $x_{28, k}=\max \left\{x_{25, k}, 0\right\}$; decision on the reduction of number is made when $x_{29, k}=\max \left\{-x_{27, k}, 0\right\}$, where $x_{28, k}$ is a rate of hiring (people per week), $x_{29, k}$ is a rate of redundancy (people per week). Stability-indicating parameter is the value $x_{30, k}$ which means a total change of the number of workers at the place of manufacture (people): $x_{30, k+1}=x_{30, k}+T\left(x_{28, k}-x_{29, k}\right)$.

\subsubsection{Equation of financial flows}

Financial flows in the model are used to assess the work of the enterprise. The following equations define the level of accounts payable:

$$
x_{31, k}=C_{3} x_{32, k}, x_{33, k+1}=x_{33, k}+T\left(x_{31, k}-x_{34, k}\right), x_{34, k}=\frac{1}{\tau_{3}} x_{33, k},
$$

where $x_{31, k}$ is a material invoice receipt (monetary units per week), $x_{32, k}$ is an input of basic materials (equivalent units per week), $C_{3}$ is a material price (monetary units), $x_{34, k}$ is costs for material purchasing (monetary units per week), $\tau_{3}$ is an invoice payment delay by the plant (weeks).

Money received for goods sold are presented in the form of bills with a third-order lag before changes in the incoming flow of funds:

$$
\begin{aligned}
& x_{35, k}=C_{4}\left(x_{1, k}+x_{36, k}\right), x_{37, k+1}=\operatorname{del} 3\left(x_{35, k}, \tau_{4}\right), \\
& x_{38, k+1}=x_{38, k}+T\left(x_{35, k}-x_{37, k}\right) .
\end{aligned}
$$

Here $x_{35, k}$ is a rate of invoice arrangement for finished products (monetary units per week), $C_{4}$ is a fixed price of the finished product (monetary units), $x_{36, k}$ is a rate of product shipment by the orders of the sales unit (units per week), $x_{37, k}$ is a rate of cash inflow for the finished goods in the enterprise cashiers (monetary units per week), del3 is a designation of the third order lag [20], $\tau_{4}$ is the plant's bill payment delay by customers (weeks), $x_{38, k}$ is bills received by the enterprise (monetary units). 
The flow of funds for salary payment is determined by the equation $x_{39, k}=C_{5} x_{26, k}$, where $x_{39, k}$ is salary costs (monetary units per week), $x_{26, k}$ is a number of personnel (people), $C_{5}$ is average salary per week (monetary units).

Taking into account the equations (8), (9), the current profit $L_{1, k}$ (monetary units per week) before payment of taxes is given by the equation:

$$
L_{1, k}=\left(C_{4}-C_{7}\right)\left(x_{1, k}+x_{36, k}\right)-C_{6}-\left[\left(u_{1, k}+x_{36, k}\right)\left(\frac{C_{5}}{C_{1}}\right)\right],
$$

where $C_{6}$ is a rate of fixed surpluses (monetary units per week), $C_{7}$ is a standard cost of product unit in reserve, $u_{1, k}$ is a production rate using production reserve. Net profit $L_{2, k}$ can be defined as a half of the total profit before payment of taxes $L_{2, k}=0,5 L_{2, k}, L_{3, k+1}=L_{3, k}+T L_{2, k}$, where $L_{2, k}$ is net profit during the period in question (monetary units).

Shareholders' dividends are determined based on the average value of net profit for the chosen period of time. At the same time their value remains unchangeable at a short-term change of the profit. The level of dividend payments $L_{4, k}$ (monetary units per week) can be determined by the equation $L_{4, k+1}=L_{4, k}+\frac{T}{p_{4}}\left(L_{2, k}-L_{4, k}\right)$, where $L_{4, k}$ is a level of dividend payments to shareholders (monetary units per week), $p_{4}$ is regulation time of the level of dividends (weeks).

\subsubsection{Control actions}

Only the values that can be changes by the enterprise administration are chosen as control actions. The coordinates of the command vector $u_{k}$ are the following: the rate of requirementmet due to production reserve $u_{1, k}$; the rate of production on request of the sale unit of the enterprise $u_{2, k}$; the rates of hiring $u_{3, k}$ and redundancy of workers $u_{4, k}$; the rate of delivery of goods to customers $u_{5, k}$; the rate of procurement of materials $u_{6, k}$.

The rate of requirements $u_{1, k}$ depends on the requirements in the process of their arrangement in the enterprise $x_{40, k}$ (units), delay in requirement arrangement in the enterprise $\tau_{2}$ (weeks) and on the size of the part of orders $C_{8}$ (arbitrary units) that can be fulfilled due to orders and has restrictions $0 \leq u_{1, k} \leq C_{8} \frac{x_{40, k}}{\tau_{2}}$. Here the expression $C_{8} \frac{x_{40, k}}{\tau_{2}}$ determines the maximum rate of requirements met due to the enterprise reserve.

Production on request of the sales unit $u_{2, k}$ is determined by the distribution of labor force, depending on the volume of the portfolio of unfilled orders. Decision on the distribution of labor force by the part that produces items for reserve and by the part, which fulfills the orders of the sales unitis made by the administration of the enterprise. The value $u_{2, k}$ is limited by inequality $\max \left\{C_{1} x_{41, k}-\frac{x_{42, k}}{T}, 0\right\} \leq u_{2, k} \leq \min \left\{C_{1} x_{41, k}, \frac{x_{43, k}}{T}\right\}$, where $x_{41, k}$ is production personnel of the enterprise (people), $x_{42, k}$ is a number of not started orders by the manufacturing unit for reserves replacement (units), $x_{43, k}$ is a number of orders (units) on request of the sales unit not fulfilled by the manufacturing unit, $C_{1}$ is a workforce productivity in the plant (units per people-weeks).

The aim set by the enterprise administration under the change of demand for the products is the stability of the number of operable enterprise. The following conditions are imposed on the rates of hiring $u_{3, k}$ and redundancy $u_{4, k}$ of labor force: $0 \leq u_{3, k}, 0 \leq u_{4, k} \leq \frac{x_{41, k}}{T}$.

When determining the delivery rate $u_{5, k}$, the enterprise administration, having the information on 


\section{Управление в социально-экономических системах}

current state of the market and forecast for the future period, can reduce the delivery rate or increase it up to critical level. The restrictions imposed on $u_{5, k}$ are given by inequality

$$
0 \leq u_{5, k} \leq \frac{1}{T} \min \left\{x_{44, k}, x_{45, k}\right\},
$$

where $x_{44, k}$ are orders (units) not fulfilled by the sales unit, $x_{45, k}$ is reserves (units) in the sales unit. The right part of the inequality (10) determines maximum value of the rate of retail product shipment, at which the whole reserves are used for the period of time $T$ in the sales unit, or all existing customer orders will be fulfilled.

The rate of material procurement $u_{6, k}$, determined by the enterprise administration as well, has restriction $0 \leq u_{6, k}$.

\section{Enterprise control}

\subsection{Enterprise adaptation to changes in the market environment}

Enterprise activities should satisfy the requirements conditioned by changes in the market environment with respond to the product demand changes. Economic performance of the enterprise can be improved by finding the optimal parameter values $p$, solving the problem of enterprise adaptation [20, 21].

The coordinates of the vector of parameters $p$ of the enterprise include product shipment delay of the manufacturing unit; delay in the creation of a product requirements document at the place of production; production time; delay in the order portfolio of the manufacturing unit; time needed for the training of workers; time of product shipments averaging from the production reserve; time of change in the flow of information about supply; minimum time of orders fulfillment by the sales unit; average delay of order distribution by the sales unit under the absence of some goods at the stock; time of inventory control in the sales unit; time of ordering in the sales unit; delay in communication channels in the sales unit; delay in the transportation of goods to the sales unit of the enterprise; profit tax rate; change time of the number of workers, etc.

Let us set the problem of parameter optimization. We shall introduce the value of lost profits, which determines how accurate the enterprise completes changes in product demand $w_{0, k}$ :

$$
L_{k+1}=L_{k}+T\left|w_{0, k}-u_{5, k}\right|, k=0,1, \ldots, N-1,
$$

where $u_{5, k}$ is a rate of product supply to customers, $N$ is given time interval, $T$ is model sampling period. The magnitude of the rate of product delivery depends on the vector of parameters of the enterprise $p$ and changes in demand $w_{0, k}$. The higher the change in demand, the greater the difference between $u_{5, k}$ and $w_{k}^{0}$, which is explained by delays due to dynamic processes in the enterprise. This increases the value of lost profits $L_{k}$, determined, ultimately, by demand and parameters of the enterprise. Knowing the values of the parameters and having the opportunity to change them, you can reduce the amount of lost profits $L_{k}$. At the same time account must be taken of the fact that any change of the parameters is associated with the costs. This requires the introduction of restrictions to changes of the parameters of the enterprise due to the limited funds allocated for the adaptation.

We shall define the problem of optimization as a problem of finding the minimum of objective function $f(p)$ along the trajectory of the model (7) at restrictions to the vector of parameters of the system $p$ :

$$
\begin{aligned}
& f(p) \rightarrow \min , \\
& p_{i}^{L} \leq p_{i} \leq p_{i}^{H}, \sum_{i=1}^{s} c_{i}\left(p_{i}^{0}-p_{i}\right) \leq R, i=1, \ldots, s .
\end{aligned}
$$

Here $p_{i}^{L}, p_{i}^{0}, p_{i}^{H}$ are minimum, maximum and starting values of the parameters, respectively; $R$ is costs spent on change of parameters; $c_{i}$ is costs spent on change of the unit of $i$ parameter, $s$ is a number of variable parameters of the system. As the search for the optimal solution occurs with limited funds, lost profit function for a given period of time $N$ can be considered as the objective function [20,21]. 
In the process of adaptation it is not enough for the enterprise to focus only on the lost profits. Such factors as the state of inventory, the status of raw materials and resources, labor force, financial status should be considered and taken into account. Therefore, this problem is multi-criteria and differs from linear programming problem in nonlinear nature of objective functions. The optimum solution to this problem may be different from the angular point of the convex target set. Since the objective functions are not convex and may have several local minima, the problem is multiextremal. When finding a global extremum, choice of starting point $p_{i}^{0}$ is carried out in random manner from the target set.

After finding the optimal parameters of the enterprise it is necessary to evaluate the adaptation efficiency based on the amount of costs for the change of parameters of the enterprise.

\subsection{Enterprise control under certainty}

After solving the problems of parametric optimization and enterprise adaptation we shall now consider the synthesis of optimal control of the enterprise. We shall assume the part of coordinates of the state vector in the expanded model (7) as control variables and present a dynamic model of the enterprise in the form of

$$
x_{k+1}=\Phi\left(x_{k}, p_{k}, w_{k}\right), k=0,1, \ldots, N-1 .
$$

Linearizing (13), we obtain

$$
x_{k+1}=A_{k} x_{k}++B_{k} u_{k}+D_{k} w_{k}, k=0,1, \ldots, N-1,
$$

where $A_{k}, B_{k}, D_{k}$ are known matrices. We shall consider initial value of the state vector $x_{0}$ and the sequence of vectors $w_{k}, k=0,1, \ldots, N-1$, to be known. Under conditions of certainty the parameter vector $p$ is constant, so it can be omitted in the matrix recording. Disturbance vector $w_{k}$, determines the current situation, and its coordinates are market factors, such as demand for products, price of materials, payment time of products, delivery time of materials, and staff turnover of the enterprise.

The functional with three main constituents that characterize the production can be considered as a criterion of control efficiency. Among the three main constituents are: the deviation of the profit from the desired value (lost profit), production costs, loss of the selling service. Each constituent in the criterion corresponds to its weighting coefficient that reflects the preferences of individuals who make management decisions and determines the strategy of survival for the enterprise on the market. Criterion construction by the example of the specified terms is given in [20-22].

The criterion of efficiency takes the form

$$
\left(x_{N}-\mu_{N}\right)^{T} S\left(x_{N}-\mu_{N}\right)+\sum_{k=1}^{N-1}\left[\left(x_{k}-\mu_{k}\right)^{T} Q\left(x_{k}-\mu_{k}\right)+\left(u_{k}-\gamma_{k}\right)^{T} R\left(u_{k}-\gamma_{k}\right)\right] \text {, }
$$

where $S, Q$ is a symmetric nonnegative definite matrix, $R$ is a symmetric positive definite matrix, $\mu_{k}, \gamma_{k}$ are given vectors with the coordinates that define normal levels of state variables, $N$ is a number of sampling intervals. The criterion reflects the effect of the enterprise losses in the transition period. Matrices $S, Q, R$ provide the reduction of the measurement units of each term of the criterion to the units, in which the corresponding variables of state and control vectors are measured.

We shall state the optimal control problem under certainty. Let the linear system of differential equations (14), describing the dynamics of the enterprise be determined, the vectors describing the initial state of a dynamic system be given, and the quality functional (15), which reflects the total loss of the company during the transition period, be defined. We need to find a sequence of command vectors of the enterprise $u_{k}, k=0,1, \ldots, N-1$, delivering the minimum value to the quality functional.

Stated problem is solved by dynamic programming. In this connection the optimal control takes the form

$$
u_{k}=-K_{k}^{1} x_{k}+K_{k}^{2} w_{k}, k=0,1, \ldots, N-1,
$$

where matrices $K_{k}^{1}, K_{k}^{2}$ are determined by the ratio

$$
K_{k}^{1}=\gamma_{k} T_{k+1}^{1} A, K_{k}^{2}=\gamma_{k}\left(T_{k+1}^{1} D+T_{k+1}^{2}\right), \gamma_{k}=\left(R+B^{T} T_{k+1}^{1} B+T_{k+1}^{2}\right)^{-1} B^{T},
$$




\section{Управление в социально-экономических системах}

and matrices $T_{k}^{1}=Q+A^{T} T_{k+1}^{1}\left(A-B K_{k}^{1}\right), T_{k}^{2}=\left(A-B K_{k}^{1}\right)^{T}\left(T_{k+1}^{1} D+T_{k+1}^{2}\right)$ are the solutions of the Riccati equation with boundary conditions $T_{N}^{1}=S, T_{N}^{2}=0$.

When the control is realized under the conditions of incomplete information, the disturbances $w_{k}$ are unknown and there is no data on the current values of the state vector $x_{k}$, it is necessary to use estimates of these vectors.

\subsection{Enterprise control under uncertainty}

When analyzing the operation of business the incompleteness and inaccuracy of data should be taken into account: it is impossible to predict in advance what the demand for the products will be, how the equipment will operate and how many workers will work. When modeling the dynamics, uncertain quantities are reported in terms of random and deterministic components. The state of the enterprise is determined by the vector of parameters $p$ and state $x_{k}$, observation of which is carried out under conditions of errors and incomplete information. Therefore, the methods of theory of guaranteed control of objects, whose operation takes place under conditions of uncertainty, should be used along with a probabilistic approach.

In the following, we shall only give the solution to the problem of estimation of the vector of state $x_{k}$ using a priori and posteriori information to control the enterprise, taking into account the incompleteness and inaccuracy of data.The solution to the problem of control synthesis is given in [21]. Weshalladdthemodelofinformationsystemtothemodelofenterprisedynamics (14), additionally introducing the summands, determining disturbances and measurement errors:

$$
\begin{aligned}
& x_{k+1}=A_{k} x_{k}+B_{k} u_{k}+D_{k} w_{k}+C_{k} \xi_{k}, \\
& y_{k+1}=G_{k} x_{k+1}+H_{k} v_{k+1}+\eta_{k+1}, k=0,1, \ldots, N-1 .
\end{aligned}
$$

Here $\xi_{k}, \eta_{k}$ are disturbances and errors of measurements are independent Gaussian sequences with known positive definite matrices of covariance $Q_{k}, R_{k}$ and zero expectations $M \xi_{k}$ and $M \eta_{k}$. Indefinite determinated actions $w_{k} \in W_{k}$ and measurement errors $v_{k} \in V_{k}$ are initially unknown, only sets $W_{k}, V_{k}$, are known, which are convex compacts. Assume matrices $A_{k}, B_{k}, C_{k}, D_{k}, H_{k}$ are also known, and let the system (17), (18) be controllable and observable. Assume initial state $x_{0}$ of the system is Gaussian vector, independent of $\xi_{k}$ and $\eta_{k}$ with known positive definite matrix of covariance $P_{0}$, but with the average $M x_{0}$ unknown beforehand, where $X_{0}$ is known convex compact. For these conditions we need to find the vector estimation $x_{k}^{*}$ at each $k$ step by total measurements $y_{k}(\cdot)=\left\{y_{1}, y_{2}, \ldots, y_{k}\right\}$. Guaranteed estimation of the system state involves the construction of the sequence of information sets $\bar{X}_{k}$ and estimations $x_{k}^{*}$, which are taken as Chebyshev center of an information set $\bar{X}_{k}[10,11,19,20]$ :

$$
\begin{aligned}
& \bar{X}_{k}=X_{k / k-1}+\Lambda_{k}\left(y_{k}-G_{k} X_{k / k-1}-H_{k} V_{k}\right), \\
& X_{k / k-1}=A_{k-1} \bar{X}_{k-1}+B_{k-1} u_{k-1}+D_{k-1} W_{k-1}, k=1,2, \ldots
\end{aligned}
$$

where $\Lambda_{k}$ is a gain of Kalman filter, characterizing the ratio between the uncertainty of state and measurement, depending on the system properties - matrices $A_{k}$ and $G_{k}$, and the totality is considered as the Minkowski meaning. Prediction locus $X_{k / k-1}$ is calculated based on the preceding set estimation $\bar{X}_{k-1}$ of the state vector of the system and managerial decision made $u_{k-1}$.

Let us reduce (19) to the form that would be suitable for real-time computation. For symmetric sets $\bar{X}_{0}, W_{k}, V_{k+1}, k=0,1, \ldots$, with regard to the designations $\bar{A}_{k-1}=\left(I-\Lambda_{k} G_{k}\right) A_{k-1}, \bar{D}_{k-1}=\left(I-\Lambda_{k} G_{k}\right) D_{k-1}$, the following evolution equations of the sets $\bar{X}_{k}$ and estimations $x_{k}^{*}$ have been obtained:

$$
\begin{aligned}
& \bar{X}_{k}=\breve{X}_{k}+z_{k}, k=1,2, \ldots, \breve{X}_{k}=\bar{A}_{k-1} \breve{X}_{k-1}+D_{k-1} W_{k-1}+\Lambda_{k} H_{k}\left(-V_{k}\right), \\
& \breve{X}_{0}=\bar{X}_{0}, k=1,2, \ldots, z_{k}=\bar{A}_{k-1} z_{k-1}+\Lambda_{k} y_{k}, z_{0}=0, \\
& x_{k}^{*}=\breve{x}_{k}+z_{k}, x_{0}^{*}=\breve{x}_{0}, \breve{x}_{k}=\bar{A}_{k-1} \breve{x}_{k-1}+B_{k-1} u_{k-1}, k=1,2, \ldots
\end{aligned}
$$


Here $z_{k}$ is a back-calculated vector $y_{k}$, matrices $\bar{A}_{k-1}, \bar{D}_{k-1}$ can be calculated and the set $\breve{X}_{k}$ can be built beforehand by a priori data.

Disturbances acting on the system do not always have a stochastic nature. In this case it is possible to use maximum estimation algorithm [13-17].

The advantage of guaranteed parameter estimation algorithm is that it does not require knowledge of the statistical characteristics of disturbances and errors, which is important under the condition when the control object is poorly known.

\section{Simulation results}

The simulation of enterprise behavior was carried out by changing its external environment in the process of experiment. The main external factor affecting the enterprise was the demand for its products. Its changes were taken as an input disturbance. The enterprise behavior was compared at nonoptimal and optimal parameters: the system response on a step $20 \%$ increase in demand was considered in comparison with the initial value taken as 1000 units per week. Optimal parameters were obtained as a result of optimization problem solution (12) for the criterion of shortfall in profits (11) in case if the restriction of costs value for a change of parameters were 20 units, and in case of no restrictions, 45.2 units were spent. Initial values of the parameters $p_{i}^{0}$ were selected by equal upper limits of the ranges of their change $p_{i}^{2}$. They also were taken as non-optimal parameters [20, 21]. The process of simulation took 200 weeks. The values of lost profit $L_{N}$ in the first case (with the limit of funds for parameter changes) were 173.45 units, and in the second one (without the limit of funds) were 170.47 units. The value of lost profit $L_{N}$ in the enterprise with non-optimal parameters was 863.5 units.

\section{Conclusion}

The economic and mathematical model of the enterprise, describing the dynamics of its functioning, has been constructed. The effect of changes in demand for products of the enterprise on its behavior has been analyzed. The problem of the enterprise adaptation in case of changes in the market environment has been solved as a problem of parametric optimization. The synthesis control problem has been solved for the quadratic performance criterion reflecting total losses of the enterprise in case of changes in the market environment. The solution of estimation problems of the state vector of the enterprise at different informational assumptions about uncertain factors has been introduced.

\section{References}

1. Forrester J.W. Industrial Dynamics. Pegasus Communications, Inc. Waltham, 1999.

2. Loon P. Dynamic Theory of the Firm: Production, Finance and Investment. Springer Science + Business Media, 2012. $194 \mathrm{p}$.

3. Mitchell M.F. The Scope and Organisation of Production: Firm Dynamics Over the Learning Curve. Rand Journal of Economics, Spring 2000, vol. 31, no. 1, pp. 180-205.

4. Beer S. Mozg firmy [Brain of the Firm]. Moscow, Librocom/URSS Publ., 2009. 416 p.

5. Beer S. Nauka upravleniya [Management Science]. Moscow, Librocom/URSS Publ., 2010. 112 p.

6. Vanurikhin G.I. [Problems of Economic Processes Management and Possibilities of Their Solution Based on Self-Organization by the Method of A.A. Krasovskii]. Automation and Telemechanics, 2001, no. 7, pp. 72-81. (in Russ.)

7. Kabanov S.A. [Management with Self-Organization as a Tool for Solving Optimization Problems in the Socio-Economic Sphere]. News of Russian Academy of Science. Theory and Control Systems, 1999, no. 3, pp. 172-176. (in Russ.)

8. Bo Zhou, Kun Qian, Xu-Dong Ma, and Xian-Zhong Dai. New Nonlinear Set Membership Filter Based on Guaranteed Bounding Ellipsoid Algorithm. Acta Automatica Sinica, 2013, vol. 39, no. 2, pp. 146-154. DOI: 10.1016/S1874-1029(13)60017-8

9. Salomatin N.A., Belyaev.V., Petrochenko.F., Proshlyakova E.V. Imitatsionnoe modelirovanie v operativnom upravlenii proizvodstvom [Simulation Modeling in Production Activity Control]. Moscow, Mashinostroenie Publ., 1984. 208 p.

10. Teoriya firmy. Vekhi ekonomicheskoi mysli [Theory of Firm. Milestones of an Economic Thought]. Saint Petersburg, Economicheskaia shkola Publ., no. 2, 1995. 534 p. 


\title{
Управление в социально-экономических системах
}

11. Sterman J.O. Business Dynamics: Systems Thinking and Modeling for a Complex World. Irwin McGraw-Hill, 2000. 982 p.

12. Waren K. Competitive Strategy Dynamics. John Wiley Sons, LTD, 2002. 330 p.

13. Shiryaev V.I., Podivilova E.O. [Approximation of Information Sets in the Problem of Guaranteed Estimation of the State of Dynamic Systems Under Conditions of Uncertainty]. Mechatronics, Automation, Control, 2014, no. 7, pp. 10-16. (in Russ.)

14. Shiryaev V.I., Podivilova E.O. Set-Valued Estimation of Linear Dynamical System State when Disturbance is Decomposed as a System of Functions. Procedia Engineering, 2015, vol. 129, pp. 252 258. DOI: 10.1016/j.proeng.2015.12.045

15. Shiryaev V.I. Synthesis of Control of Linear Systems in Incomplete Information. Journal of Computer and Systems Sciences International, 1994, no. 3, pp. 229-237.

16. Shiryaev V.I. Problems of Control by Dynamic Systems with Incomplete Information. Mechatronics, 2001, no. 8, pp. 2-5.

17. Kuntsevich V.M., Kuntsevich A.V. Invariant Sets of the Set of Linear and Nonlinear Discrete Systems with Restricted Disturbances. Automatics and Telemechanics, 2012, no. 1, pp. 92-106.

18. Kuntsevich V.M., Kurzhanskii A.B. [Fields of Achievement of Linear and Some Classes of Nonlinear Systems of Discrete Systems and Their Control]. Problems of Control and Information Science, 2010, no. 1, pp. 5-21. (in Russ.)

19. Shiryaev V.I., Shiryaev E. V., Golovin I.Ya., Smolin V.V. Adaptation and Optimal Control of a Firm and its State and Parameters Estimation at the Change of a Market Situation. Proc. of the 20-th International Conference of the System Dynamics Society. July 28-August 1, 2002. Palermo, Italy, pp. 131-132.

20. Shiryaev V.I., Shiryaev E.V. Upravlenie biznes-protsessami [Business Process Management]. Moscow, Finance and Statistics; Infra-M Publ., 2014. 464 p.

21. Shiryaev V.I., Shiryaev E.V. Prinyatie resheniy: Dinamicheskie zadachi. Upravlenie firmoy. [Decision Making: Dynamical Problems. Company Management]. Moscow, Librocom/URSS Publ., 2016. $192 \mathrm{p}$.

22. Golovin I.Ya., Shiryaev V.I. [Optimal Control of the Enterprise Under the Known Condition of Changes in the Demand for Products]. News of Russian Academy of Science. Theory and Control Systems, 2001, no. 4, pp. 95-101. (in Russ.)

23. Smolin V.V., Shiryaev V.I. [Estimation of Unknown Parameters and the State of Micro Systems Under the Conditions of Uncertainty Illustrated by Manufacturing and Sales Enterprise]. News of Russian Academy of Science. Theory and Control Systems, 2003, no. 6, pp. 68-72. (in Russ.)

Received 10 November 2016

\section{АЛГОРИТМЫ ОЦЕНИВАНИЯ И УПРАВЛЕНИЯ ПРОЦЕССАМИ ПРОИЗВОДСТВА И СБЫТА В УСЛОВИЯХ НЕПОЛНОТЫ ИНФОРМАЦИИ}

\author{
В.И. Ширяев, А.А. Брагина \\ Южно-Уральский государственный университет, г. Челябинск
}

\begin{abstract}
Рассмотрены подходы к управлению предприятием в условиях определенности и неопределенности. Построена экономико-математическая модель производственно-сбытового предприятия в виде нелинейных разностных уравнений, определяющих взаимосвязь материальных, информационных и финансовых потоков внутри предприятия, что позволяет решать задачи анализа и управления экономическими процессами как в целом на предприятии, так и в отдельных его подразделениях. Рассмотрено решение одной из возможных задач адаптации
\end{abstract}


предприятия к изменяющимся условиям рынка, приведена методика оценки эффективности адаптации. Сформулированы и решены задачи оптимизации параметров предприятия и оптимального управления поведением предприятия в условиях неполноты информации и изменении ситуации на рынке. Для условий неполной информации получен алгоритм оценивания вектора состояния системы. Приведены результаты моделирования. Экономико-математическая модель и алгоритмы оценивания и управления могут быть применены при разработке математического обеспечения автоматизированных систем управления предприятием.

Ключевые слова: оптимизаџия параметров, адаптация, оптимальное управление, управление в условиях неполноты информации, фильтрация, гарантированное оценивание.

\section{Лumepamypa}

1. Forrester, J.W. Industrial Dynamics / J.W. Forrester. - Pegasus Communications, Inc. Waltham, 1999.

2. Loon, P. Dynamic Theory of the Firm: Production, Finance and Investment / P. Loon. - Springer Science + Business Media, 2012. - 194 p.

3. Mitchell, M.F. The Scope and Organisation of Production: Firm Dynamics over the Learning Curve / M.F. Mitchell // Rand Journal of Economics. - Spring 2000. - Vol. 31, no. 1. - P. 180-205.

4. Бир, С. Мозг фирмы / С. Бир. - М.: Книжный дом «Либроком»/URSS, 2009. - 416 c.

5. Бир, С. Наука управления / С. Бир. - М.: Книжный дом «Либроком»/URSS, 2010. - 112 c.

6. Ванюрихин, Г.И. Проблемы управления экономическими прочессами и возможности их решения на основе самоорганизачии по А.А. Красовскому / Г.И. Ванюрихин // Автоматика и телемеханика. - 2001. - № 7. - С. 72-81.

7. Кабанов, С.А. Управление с самоорганизацией как инструмент для решения оптимизационных задач в сочиально-экономической сфере / С.А. Кабанов // Изв. РАН. Теория и системы управления. - 1999. - № 3. - С. 172-176.

8. New nonlinear set membership filter based on guaranteed bounding ellipsoid algorithm / Bo Zhou, Kun Qian, Xu-Dong Ma, and Xian-Zhong Dai // Acta Automatica Sinica. - 2013. - Vol. 39, no. 2. - P. 146-154. DOI: 10.1016/S1874-1029(13)60017-8

9. Имитационное моделирование в оперативном управлении производством / Н.А. Саломатин, Г.В. Беляев, В.Ф. Петроченко, Е.В. Прошлякова. - М.: Машиностроение, 1984. - 208 с.

10. Теория фирмы / под ред. В.М. Гальперина. - СПб.: Экон. школа, 1995. - Вып. 2. - 534 с. (Вехи экономической мысли).

11. Sterman, J.O. Business Dynamics: Systems Thinking and Modeling for a Complex World / J.O. Sterman. - Irwin McGraw-Hill, 2000. - 982 p.

12. Waren, K. Competitive Strategy Dynamics / K. Waren. - John Wiley Sons, LTD, 2002. - 330 p.

13. Ширяев, В.И. Аппроксимация информационных множеств в задаче гарантированного оценивания состояния динамических систем в условиях неопределенности / В.И. Ширяев, Е.О. Подивилова // Мехатроника, автоматизаиия, управление. - 2014. - № 7. - C. 10-16.

14. Shiryaev, V.I. Set-valued estimation of linear dynamical system state when disturbance is decomposed as a system of functions / V.I. Shiryaev, E.O. Podivilova // Procedia Engineering. - 2015. Vol. 129. - P. 252-258. DOI: 10.1016/j.proeng.2015.12.045

15. Shiryaev, V.I. Synthesis of control of linear systems in incomplete information / V.I. Shiryaev // Journal of Computer and Systems Sciences International. - 1994. - No. 3. - P. 229-237.

16. Shiryaev, V.I. Problems of control by dynamic systems with incomplete information / V.I. Shiryaev // Mechatronics. - 2001. - No. 8. - P. 2-5.

17. Kuntsevich, V.M. Invariant sets of the set of linear and nonlinear discrete systems with restricted disturbances / V.M. Kuntsevich, A.V. Kuntsevich // Automatics and telemechanics. - 2012. No. 1. - P. 92-106.

18. Кунцевич, В.М. Области достижимости линейных и некоторых классов нелинейных дискретных систем и управления ими / В.М. Кунцевич, А.Б. Куржанский // Проблемы управления и информатики. - 2010. - № 1. - C. 5-21.

19. Adaptation and Optimal Control of a Firm and its State and Parameters Estimation at the Change of a Market Situation / V.I. Shiryaev, E.V. Shiryaev, I.Ya. Golovin, V.V. Smolin // Proceedings 


\section{Управление в социально-экономических системах}

of the 20-th International Conference of the System Dynamics Society. July 28-August 1, 2002. - Palermo, Italy, 2002. - P. 131-132.

20. Ширяев, В.И. Управление бизнес-прочессами / В.И. Ширяев, Е.В. Ширяев. - М.: Финансы и статистика; Инфра-М, 2014. - 464 с.

21. Ширяев, В.И. Принятие решений: Динамические задачи. Управление фирмой / В.И. Ширяев, Е.В. Ширяев. - М.: Книжный дом «Либроком»/URSS, 2016. - 192 c.

22. Головин, И.Я. Оптимальное управление фирмой при известном изменении спроса на продукиию / И.Я. Головин, В.И. Ширяев // Изв. РАН. Теория и системы управления. - 2001. - № 4. C. $95-101$.

23. Смолин, В.В. Оченивание неизвестных параметров и состояния микроэкономических систем в условиях неопределенности на примере производственно-сбытовой фирмы / В.В. Смолин, В.И. Ширяев // Изв. РАН. Теория и системы управления. - 2003. - № 6. - С. 68-72.

Ширяев Владимир Иванович, д-р техн. наук, профессор, Южно-Уральский государственный университет, г. Челябинск; shiriaevvi@susu.ru.

Брагина Асия Ахмедовна, канд. техн. наук, доцент, Южно-Уральский государственный университет, г. Челябинск; braginaaa@susu.ru.

Поступила в редакцию 10 ноября 2016 2.

\section{ОБРАЗЕЦ ЦИТИРОВАНИЯ}

Shiryaev, V.I. Estimation and Control Algorithms of Manufacturing and Sales Processes under Conditions of Incomplete Information / V.I. Shiryaev, A.A. Bragina // Вестник ЮУрГУ. Серия «Компьютерные технологии, управление, радиоэлектроника». - 2017. - Т. 17, № 1. C. $91-102$. DOI: $10.14529 /$ ctcr 170110

\section{FOR CITATION}

Shiryaev V.I., Bragina A.A. Estimation and Control Algorithms of Manufacturing and Sales Processes under Conditions of Incomplete Information. Bulletin of the South Ural State University. Ser. Computer Technologies, Automatic Control, Radio Electronics, 2017, vol. 17, no. 1, pp. 91-102. DOI: $10.14529 /$ ctcr 170110 